\title{
Light-Mediated Sulfenic Acid Generation from Photocaged Cysteine Sulfoxide
}

\author{
Jia Pan and Kate S. Carroll ${ }^{\star}$ \\ The Scripps Research Institute, Scripps Florida, 130 Scripps Way, Jupiter, FL 33458
}

\begin{abstract}
S-Sulfenylation is a post-translational modification with crucial role in regulating protein function. However, its analysis has remained challenging due to the lack of facile sulfenic acid models. We report the first photocaged cysteine sulfenic acid with efficient photodeprotection, and demonstrate its utility by generating sulfenic acid in a thiol peroxidase after illumination in vitro. These caged sulfoxides should be promising for site-specific incorporation of Cys sulfenic acid in living cells via genetic code expansion.
\end{abstract}

\section{Graphical abstract}
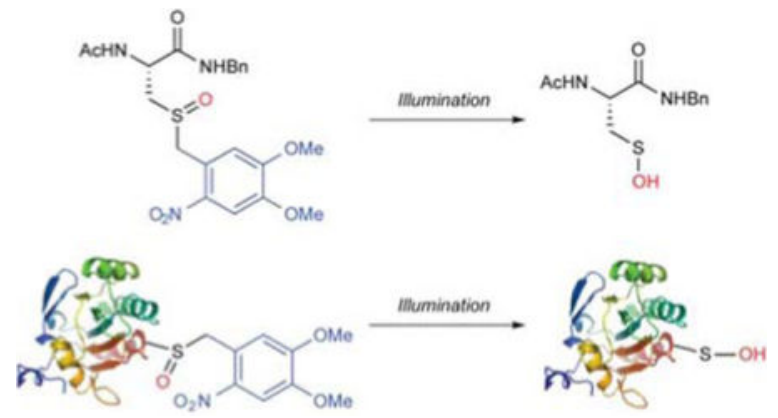

The amino acid cysteine plays an essential role in redox signal transduction owing to its susceptibility to oxidation by various reactive oxygen species (ROS). ${ }^{1}$ Among possible oxidative post-translational modifications of cysteine (Cys), S-sulfenylation has become the subject of growing attention in recent years. ${ }^{2}$ During redox signaling or under conditions of oxidative stress, a reactive Cys thiol (-SH) can be oxidized to sulfenic acid (-SOH) by ROS, namely hydrogen peroxide $\left(\mathrm{H}_{2} \mathrm{O}_{2}\right)$, and this process can be reversed by biological reductants, such as the enzyme, thioredoxin ${ }^{3}$ (Trx) or the tripeptide, glutathione ${ }^{4}$ (GSH) (Scheme 1). To date, regulatory Cys sulfenic acid modifications have been identified in many signaling proteins such as tyrosine phosphatases, ${ }^{5}$ kinases, ${ }^{6}$ transcription factors, ${ }^{7}$ proteases, ${ }^{8}$ deubiquitinases ${ }^{9}$ and ion channels. ${ }^{10}$ Aberrant protein sulfenylation has also been correlated with human pathologies, including cancer ${ }^{11}$ and cardiovascular disease. ${ }^{10}$

\footnotetext{
*Corresponding Author: kcarroll@scripps.edu.

Supporting Information

Experimental procedures and spectroscopic data. This material is available free of charge via the Internet at http://pubs.acs.org.
} 
While protein sulfenylation is an important post-translational modification, the analysis of this Cys oxoform has remained challenging due to the lack of facile sulfenic acid model systems. The challenge is significant given that sulfenic acids are often unstable, transient species that can rapidly react to form thiosulfinate and disulfide species. ${ }^{2}$ Some progress has been made in defining sulfenic acid stabilization and properties in small-molecule models such as $1^{12}$ and $2^{13}$ (Figure 1); however, such compounds still suffer from complex syntheses, poor aqueous solubility, do not adequately recapitulate the characteristics or reactivity of Cys sulfenic acid and cannot be stored for an extended period of time. In proteins, the stability of Cys sulfenic acid is determined by the surrounding microenvironment and the absence of vicinal thiols ${ }^{14}$ and presence of basic residues ${ }^{15}$ are often cited as key features. Protein sulfenic acid formation in vitro and in cells is most often achieved by incubation with exogenous oxidants like $\mathrm{H}_{2} \mathrm{O}_{2}$, organo hydroperoxides, ${ }^{20}$ or elevating endogenous ROS production via treatment with growth factor or insulin. ${ }^{10}$ Nevertheless, uncontrolled oxidation of reactive Cys residue(s) stemming from such methods often makes it difficult to study sulfenylation of specific proteins at defined sites within redox signaling pathways.

Caged compounds are precursors of biologically active molecules that have been rendered inactive by installation of a photolabile protecting group (PPG) onto the essential functionality. ${ }^{16}$ After illumination, the PG is cleaved and the caged biomolecule is released irreversibly, thus revealing the active species. Photocaged Cys has been site-specifically incorporated to study thiol function and targeted covalent labeling in small molecules, ${ }^{17}$ peptides, ${ }^{18}$ and proteins. ${ }^{19}$ Photocaged selenocysteine has also been reported. ${ }^{20}$ Despite these encouraging advances and the benefits of photocontrol, methods to incorporate defined Cys "oxoforms", such as sulfenic acid have not yet been described. Herein, we report the first photocaged Cys sulfenic acid analogs and establish conditions for efficient photodeprotection. We demonstrate the utility of this approach by generating Cys sulfenic acid in a thiol peroxidase, following illumination in vitro. Overall, these photocaged cysteine sulfenic acid analogs should have considerable utility for the site-specific incorporation of Cys sulfenic acid within small-molecules, proteins, and eventually, in living cells via genetic code expansion.

In the current investigation, we have explored a novel strategy based on a photolabile (ortho-nitrobenzyl, ONB or 4,5-dimethoxy-2-nitrobenzyl, DMNB) group to protect Cys sulfoxide (CysO) analogs (Scheme 2). In this approach, we reasoned that PG cleavage would proceed via benzoisoxazole $\mathbf{4}$, which would rearrange to give a-hydroxyl sulfoxide $\mathbf{5}$, and conclude with elimination of 6 to give sulfenic acid 7 . We first focused our attention on the chemical synthesis of ortho-nitrobenzyl (ONB) and 4,5-dimethoxy-2nitrobenzyl (DMNB) CysO and Cys analogs, such that photocleavage and reactivity of $\mathrm{CysO}$ and its reduced counterpart could be effectively compared (Scheme 3). In short, photocaged Cys compounds $(\mathbf{8 a}, \mathbf{8 b})$ were generated from $\mathrm{N}$-acetylcysteine benzylamide $\mathbf{9}$ upon literature procedures ${ }^{17}$. Subsequently, oxidation of photocaged Cys analogs to corresponding sulfoxides (3a, 3b) was achieved using $\mathrm{H}_{2} \mathrm{O}_{2}$ in the presence of acetic acid in excellent yields ( $\geq 90 \%$ ). In the absence of illumination, all compounds were stable in aqueous media at neutral $\mathrm{pH}$ values, as expected (Figure S1).

Org Lett. Author manuscript; available in PMC 2016 December 18. 
Next, we tested whether we could observe the formation of sulfenic acid from model caged sulfoxide $3 b$. Illumination of $\mathbf{3 b}\left(\lambda_{\max }=350 \mathrm{~nm}, \varepsilon_{350 \mathrm{~nm}}=18590 \mathrm{M}^{-1} \mathrm{~cm}^{-1}, \varepsilon_{365 \mathrm{~nm}}=16500\right.$ $\left.\mathrm{M}^{-1} \mathrm{~cm}^{-1}, \Phi_{\text {chem }}=0.13\right)$ with UV light at $365 \mathrm{~nm}\left(0.35 \mathrm{watt} / \mathrm{cm}^{2}\right)$ led to complete consumption of $\mathbf{3 b}$ and formation of sulfinic acid $\mathbf{1 0}$ (45\% yield) and disulfide $\mathbf{1 1}$ (39\% yield) as the major products (Scheme 4A). Formation of these products can be explained due to the disproportionation reaction of sulfenic acid to sulfinic acid $\mathbf{1 0}$ and a thiol, which then reacts with sulfenic acid to give disulfide $\mathbf{1 1} .^{21}$ By measuring the consumption of $\mathbf{3 b}$, the pseudo first order rate constant $\left(k_{\mathrm{obs}}\right)$ for photocleavage was determined to be $0.17 \mathrm{~min}^{-1}$ (Scheme 4B and Figure S2 and S3).

To verify formation of the expected sulfenic acid product, we exploited the dual electrophilic and nucleophilic reactivity of this sulfur oxoform. ${ }^{1 f, 2 b}$ When N-ethylmaleimide (NEM) was added to the reaction, the anticipated sulfoxide-NEM adduct $\mathbf{1 2}$ was formed (36\% yield, Scheme 5A). ${ }^{22}$ Correspondingly, when carbon-based nucleophiles like piperidine-2,4-dione (PD) ${ }^{23}$ were included to trap the nacent sulfenic acid, the expected sulfide adduct 13 was observed ( $80 \%$ yield, Scheme 5A). Control experiments, performed under the same reaction conditions, clearly demonstrate that caged Cys analog $\mathbf{8 b}$ formed the appropriate sulfide adduct 14 with NEM ( $42 \%$ yield) and did not react with the PD nucleophile (Scheme 5B). ${ }^{24}$ These data establish formation of sulfenic acid from the caged sulfoxide starting material, as anticipated by our strategy.

To determine whether our approach could be applied to proteins, we next examined photolytic generation of Cys sulfenic acid from a DMNB-protected sulfoxide precursor in the thiol peroxidase, Gpx3 (Cys64Ser Cys82Ser Gpx3 was used to avoid multiple alkylation events). Caged Gpx3 Cys32 sulfoxide, termed Cys320, was prepared by alkylation of the catalytic Cys32 of Gpx3 with dimethoxy-o-nitrobenzyl bromide (DMNB-Br), followed by oxidation with $\mathrm{H}_{2} \mathrm{O}_{2}$. During the oxidation step, we observed that methionines (Met) in Gpx3 were converted to Met sulfoxide (MetO) (expanded intact ESI-MS spectra presented in Figure S4). ${ }^{25}$ As shown in Scheme 6A, illumination of Gpx3 Cys320-DMNB at $365 \mathrm{~nm}$ followed by intact ESI-MS demonstrates the full conversion of the DMNB-caged sulfoxide to Gpx3 Cys32 sulfenic acid, with nearly quantitative trapping of this intermediate by the PD nucleophile. Control photo-uncaging experiments, in which Gpx3 Cys32 was alkylated with DMNB-Br, but not oxidized with $\mathrm{H}_{2} \mathrm{O}_{2}$, did not lead to the formation of PD-tagged Gpx3, as expected (Figure S3). A time course study was also carried out to show controllable release of Gpx3 sulfenic acid via consumption of caged Gpx3 Cys320 $\left(k_{\mathrm{obs}}=\right.$ $\left.0.013 \mathrm{~min}^{-1}\right)$ and robust formation of the anticipated Gpx3-PD adduct $\left(k_{\mathrm{obs}}=0.011 \mathrm{~min}^{-1}\right.$, Scheme 6B). Although removal of additional Cys residues and Met oxidation may limit the utility of our approach in this context, these experiments serve as an important proof-ofprinciple that CysO-DMNB can be efficiently uncaged in a protein model to afford Cys sulfenic acid.

Many applications of this approach can be envisioned and we are particularly interested in the ability to genetically encode the site-specific incorporation ${ }^{26,27}$ of a photocaged Cys sulfenic acid residue into a target protein within cells. Evolution of the requisite orthogonal synthetase/tRNA pair to incorporate the aforementioned unnatural amino acid (UAA) will be reported in due course. At this stage, however, given structural similarity with MetO we 
deemed it essential to test whether caged CysO 15 (analog of 3a with free amino and carboxylate groups, Figure 2A) would be a substrate for the MetO repair enzyme, (MsrA). ${ }^{28}$ As shown in Figure 2B, MetO was efficiently reduced by MsrA, while $\mathbf{1 5}$ remained intact. These data demonstrate that photocaged $\mathrm{CysO}$ is not a substrate for MsrA, which bodes well for the intracellular stability and application of caged Cys sulfoxide toward genetic encoding of Cys sulfenic acid in future work.

In summary, we have designed, synthesized, and evaluated first-in-class photocaged cysteine sulfenic acid analogs. From practical and conceptual standpoints, this work represents an important advance for the thiol-based redox regulation and chemical biology communities due to the potential for site-specific incorporation of an oxidative cysteine post-translational modification. From a chemistry perspective, caged sulfenic acids should find broad application owing to their facile preparation and storage within a large range of scaffolds, including peptides and proteins. Evolution of the requisite orthogonal synthetase/ tRNA pair for site-specific incorporation of Cys sulfenic acid within living cells via genetic code expansion is currently underway and will be reported in due course.

\section{Supplementary Material}

Refer to Web version on PubMed Central for supplementary material.

\section{Acknowledgments}

This work was supported by the National Institutes of Health (GM102187 and CA174864 to K.S.C.). We also thank Dr. Pra-kash Palde (The Scripps Research Institute) for his support on this project.

\section{References}

1. (a) Reddie KG, Carroll KS. Curr Opin Chem Biol. 2008; 12:746. [PubMed: 18804173] (b) Paulsen CE, Carroll KS. ACS Chem Biol. 2010; 5:47. [PubMed: 19957967] (c) Miki H, Funato YJ. Biochem. 2012; 151:255.(d) Jacob C, Battaglia E, Burkholz T, Peng D, Bagrel D, Montenarh M. Chem Res Toxicol. 2012; 25:588. [PubMed: 22106817] (e) Chung HS, Wang SB, Venkatraman V, Murray CI, Van Eyk JE. Circ Res. 2013; 112:382. [PubMed: 23329793] (f) Paulsen CE, Carroll KS. Chem Rev. 2013; 113:4633. [PubMed: 23514336]

2. (a) Lo Conte M, Carroll KS. J Biol Chem. 2013; 288:26480. [PubMed: 23861405] (b) Gupta V, Carroll KS. Biochim Biophys Acta, Gen Subj. 2013; 1840:847.(c) Pan J, Carroll KS. Biopolymers. 2014; 101:165. [PubMed: 23576224]

3. (a) Claiborne A, Miller H, Parsonage D, Ross RP. FASEBJ. 1993; 7:1483.(b) Crane EJ 3rd, Parsonage D, Poole LB, Claiborne A. Biochemistry. 1995; 34:14114. [PubMed: 7578008] (c) Kim HY, Kim JR. Biochem Biophys Res Commun. 2008; 371:490. [PubMed: 18452709] (d) Depuydt M, Leonard SE, Vertommen D, Denoncin K, Mor-somme P, Wahni K, Messens J, Carroll KS, Collet JF. Science. 2009; 326:1109. [PubMed: 19965429]

4. (a) Mieyal JJ, Gallogly MM, Qanungo S, Sabens EA, Shelton MD. Antioxid Redox Signal. 2008; 10:1941. [PubMed: 18774901] (b) Town-send DM. Molecular Interventions. 2008; 7:313.

5. (a) Denu JM, Tanner KG. Biochemistry. 1998; 37:5633. [PubMed: 9548949] (b) Salmeen A, Andersen JN, Myers MP, Meng TC, Hinks JA, Tonks NK, Barford D. Nature. 2003; 423:769. [PubMed: 12802338] (c) Micha-lek RD, Nelson KJ, Holbrook BC, Yi JS, Stridiron D, Daniel LW, Fetrow JS, King SB, Poole SB, Grayson JM. J Immunol. 2007; 179:6456. [PubMed: 17982034]

6. (a) Paulsen CE, Truong TH, Garcia FJ, Homann A, Gupta V, Leonard SE, Carroll KS. Nat Chem Biol. 2011; 8:57. [PubMed: 22158416] (b) Warn R, Qian J, Yin L, Bechtold E, King SB, Poole LB, Paek E, Tsang AW, Furdui CM. Proc Natl Acad Sci USA. 2011; 108:10550. [PubMed: 21670275]

Org Lett. Author manuscript; available in PMC 2016 December 18. 
7. (a) Lee C, Lee SM, Mukhopadhyay P, Kim SJ, Lee SC, Ahn WS, Yu MH, Storz G, Ryu SE. Nat Struct Mol Biol. 2004; 11:U79.(b) Reynaert NL, van der Vliet A, Guala AS, McGovern T, Hristova M, Pantano C, Heintz NH, Heim J, Ho YS, Matthews DE, Wouters EF, Janssen-Heininger YM. Proc Natl Acad Sci USA. 2006; 103:13086. [PubMed: 16916935] (c) Marinho HS, Real C, Cyrne L, Soares H, Antunes F. Redox Biol. 2014; 2:535. [PubMed: 24634836]

8. (a) Claiborne A, Miller H, Parsonage D, Ross RP. FASEB J. 1993; 7:1483. [PubMed: 8262333] (b) Percival MD, Ouellet M, Campagnolo C, Claveau D, Li C. Biochemistry. 1999; 38:13574. [PubMed: 10521264]

9. Kulathu Y, Garcia FJ, Mevissen TE, Busch M, Ar-naudo N, Carroll KS, Barford D, Komander D. Nat Commun. 2013; 4:1569. [PubMed: 23463012]

10. Svoboda LK, Reddie KG, Zhang L, Vesely ED, Williams ES, Schumacher SM, O'Connell RP, Shaw R, Day SM, Anumonwo JM, Carroll KS, Martens JR. Circ Res. 2012; 111:842. [PubMed: 22843785]

11. Seo YH, Carroll KS. Proc Natl Acad Sci USA. 2009; 106:16163. [PubMed: 19805274]

12. Fries K. Chem Ber. 1912; 45:2965.

13. (a) Goto K, Tokitoh N, Okazaki R. Angew Chem Int Ed. 1995; 34:U24.(b) Saiki T, Goto K, Tokitoh N, Okazaki R. J Org Chem. 1996; 61:2924. [PubMed: 11667144] (c) Goto K, Holler M, Okazaki R. J Am Chem Soc. 1997; 119:1460.

14. (a) Allison WS. Ace Chem Res. 1976; 9:293.(b) Miller H, Claiborne A. J Biol Chem. 1991; 266:19342. [PubMed: 1918050] (c) Sohn J, Rudolph J. Biochemistry. 2003; 42:10060. [PubMed: 12939134] (d) Buhrman G, Parker B, Sohn J, Rudolph J, Mattos C. Biochemistry. 2005; 44:5307. [PubMed: 15807524]

15. Salsbury FR, Knutson ST, Poole LB, Fetrow JS. Protein Sci. 2008; 17:299. [PubMed: 18227433]

16. Mayer G, Heckel A. Angew Chem Int Ed. 2006; 45:4900.

17. Smith AB, Savinov SN, Manjappara UV, Chaiken IM. Org Lett. 2002; 4:4041. [PubMed: 12423081]

18. (a) Rothman DM, Vazquez ME, Vogel EM, Imperiali B. Org Lett. 2002; 4:2865. [PubMed: 12182575] (b) Kotzur N, Briand B, Beyermann M, Hagen V. J Am Chem Soc. 2009; 131:16927. [PubMed: 19863095] (c) Kotzur N, Briand B, Beyermann M, Hagen V. Chem Commun. 2009; $14: 3255$.

19. (a) Ghosh M, Song X, Mouneimne G, Sidani M, Lawrence S, Condeelis JDS. Science. 2004; 304:743. [PubMed: 15118165] (b) Chang CY, Niblack B, Walker B, Bayley H. Chem Biol. 1995; 2:391. [PubMed: 9383441] (c) Chang CY, Fernandez T, Panchal R, Bayley H. J Am Chem Soc. 1998; 120:7661.(d) Arabaci G, Guo XC, Beebe KD, Coggeshall KM, Pei D. J Am Chem Soc. 1999; 121:5085.

20. Rakauskaite R, Urbanaviciute G, Ruksenaite A, Liutkeviciute Z, Juskenas R, Masevicius V, Klimasauskas S. Chem Commun. 2015; 51:8245.

21. (a) Davis FA, Jenkins RH, Rizvi SQA, Yocklovich SG. J Org Chem. 1981; 46:3467.(b) Nagy P, Ashby T. Chem Res Toxicol. 2007; 20:1364. [PubMed: 17764150] (c) Nagy P, Winterbourn CC. Adv Mol Toxicology. 2010; 4:183.(d) Acharjee SR, Bhattacharjee SK. IOSRJ Appl Chem. 2013; 3:40.

22. Another major product was sulfide adduct 14 in $33 \%$ yield.

23. Gupta, V.; Carroll, K. S. 2015, DOI: 10.1039/C5SC02569A.

24. The uncaging of $\mathbf{8 b}$ was less effective than $\mathbf{3 b}$, and almost half of $\mathbf{8 b}$ remained unreacted after $3 \mathbf{h}$. In the reaction of $8 \mathrm{~b}$ with PD the major product was reduced cysteine analog 9.

25. Seven Met in Gpx3 are oxidized to Met sulfoxide.

26. Lemke EA, Summerer D, Geierstanger BH, Brittain SM, Schultz PG. Nat Chem Biol. 2007; 3:769. [PubMed: 17965709]

27. (a) Wu N, Deiters A, Cropp TA, King D, Schultz PG. J Am Chem Soc. 2004; 126:14306. [PubMed: 15521721] (b) Deiters A, Groff D, Ryu Y, Xie J, Schultz PG. Angew Chem Int Ed. 2006; 45:2728.

28. (a) Lowther WT, Brot N, Weissbach H, Matthews BW. Biochemistry. 2000; 30:13307. [PubMed: 11063566] (b) Weissbach H, Etienne F, Hoshi T, Heinemann SH, Lowther WT, Matthews B, John

Org Lett. Author manuscript; available in PMC 2016 December 18. 
GS, Nathan C, Brot NArch. Biochem Biophys. 2002; 397:172.(c) Boschi-Muller S, Gand A, Branlant G. Arch Biochem Biophys. 2008; 474:266. [PubMed: 18302927] 
<smiles>O=C1c2ccccc2C(=O)c2c1cccc2S(=O)(=O)O</smiles>

1

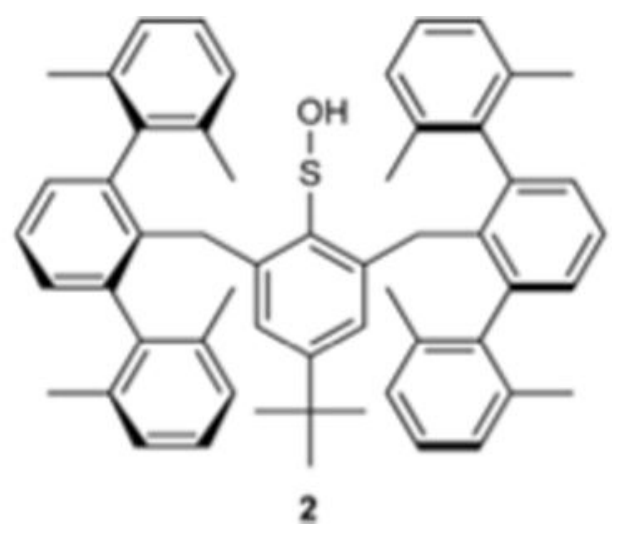

Figure 1.

Examples of small-molecule sulfenic acids stabilized via an intramolecular hydrogen bond (1) or steric effects (2). 
A.<smiles>N[C@H](CS(=O)Cc1ccccc1[N+](=O)[O-])C(=O)O</smiles>

B.

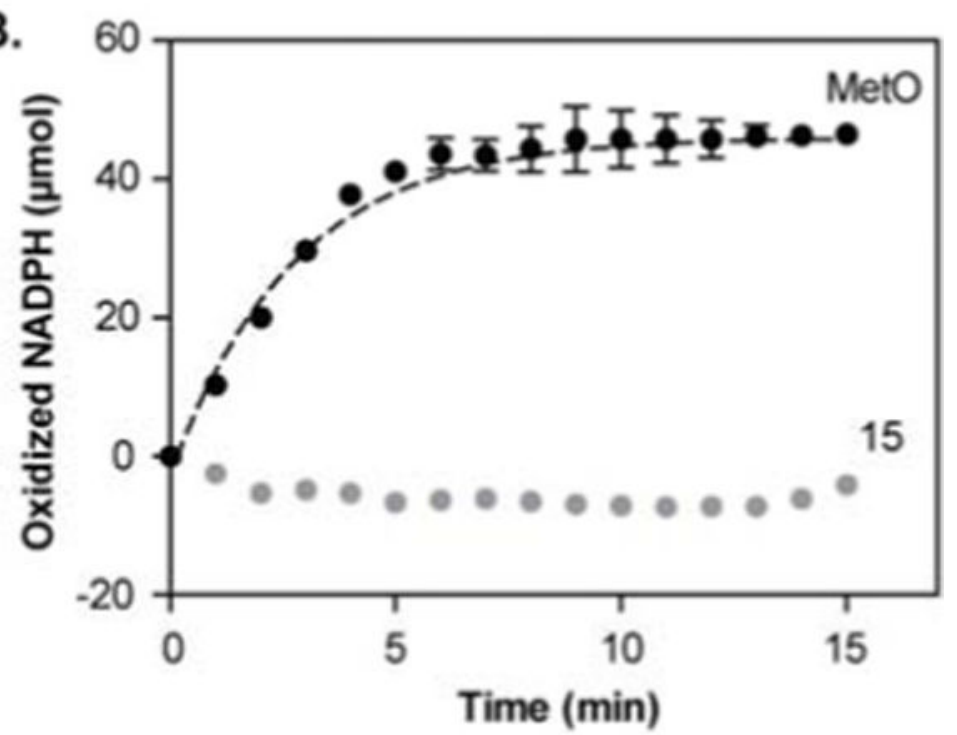

Figure 2.

A) Unprotected analog of 3a. B) MsrA activity assay with sulfoxide $\mathbf{1 5}(\bigcirc)$ and MetO (•) as putative substrates. 


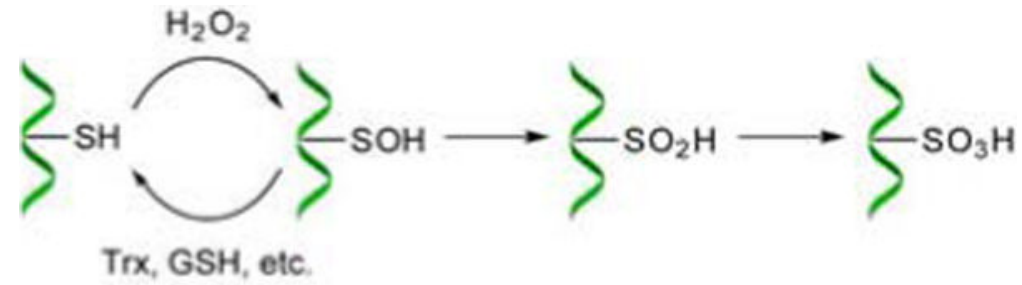

Scheme 1.

Biologically relevant cysteine oxoforms. 
<smiles>[R][SH]O[SH](C)Cc1cc([R])c([N+](=O)[O-])cc1[R]</smiles>

$3 a, R=H$

3b, $\mathrm{R}=\mathrm{OMe}$
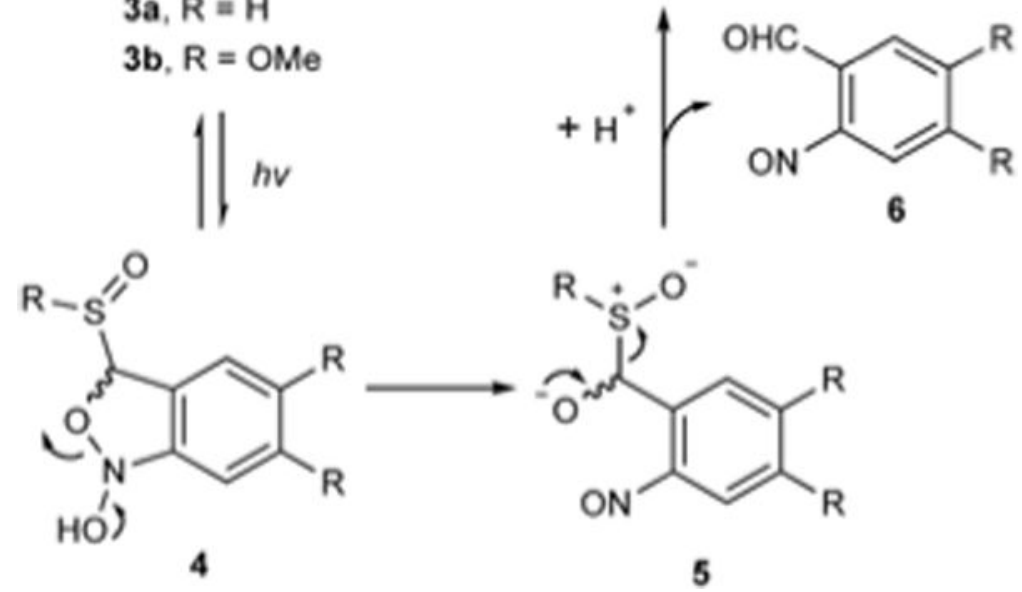

Scheme 2.

Proposed mechanism for formation of sulfenic acid from caged sulfoxide species via illumination 

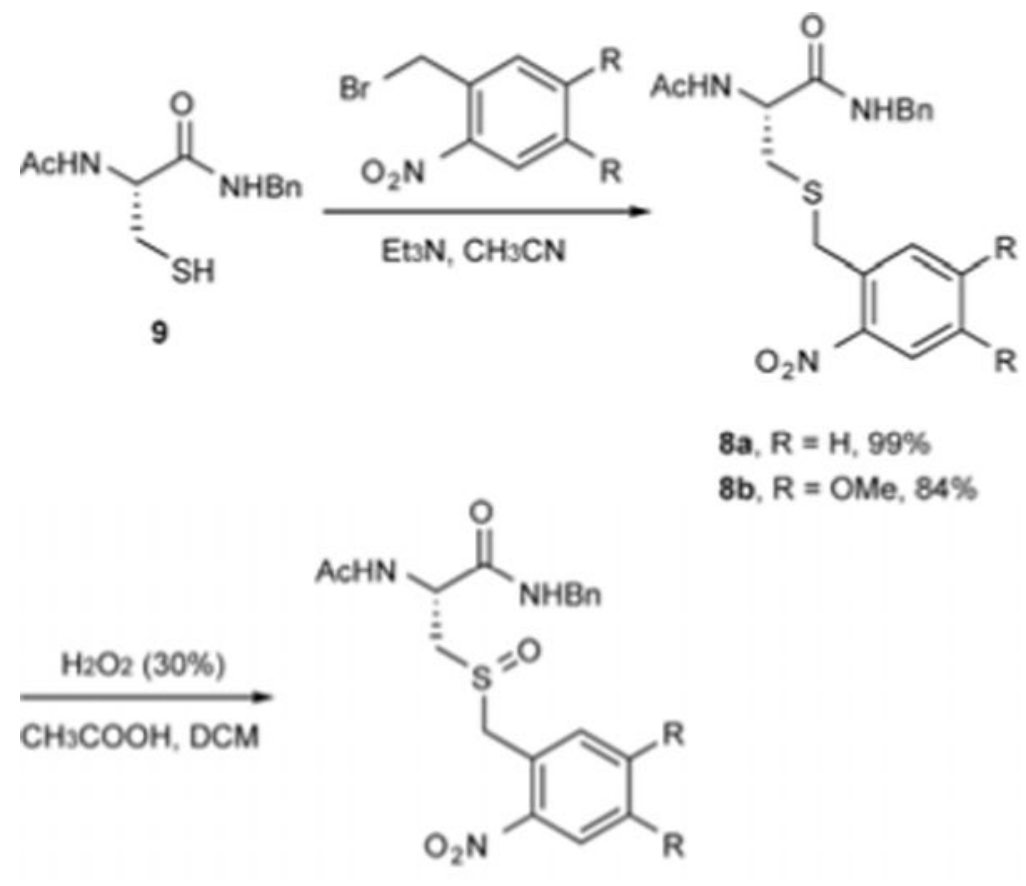

8a, $R=H, 99 \%$

3a, $R=H, 90 \%$

3b, $R=O M e, 97 \%$

Scheme 3.

Synthesis of caged sulfoxides $3 a$ and $3 b$. 
A.
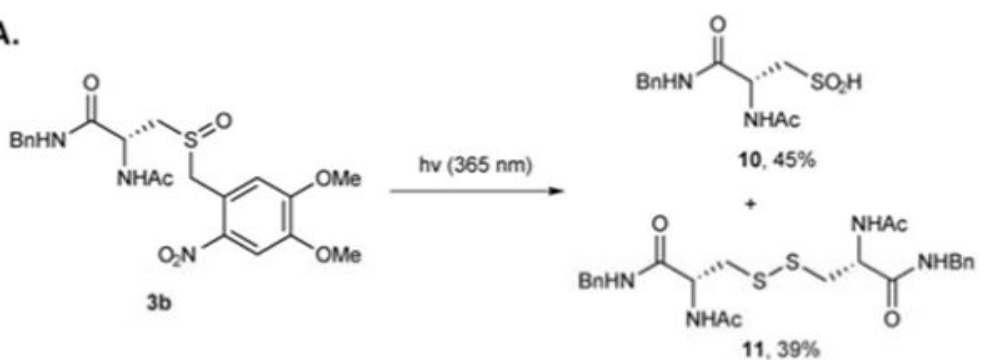

B.

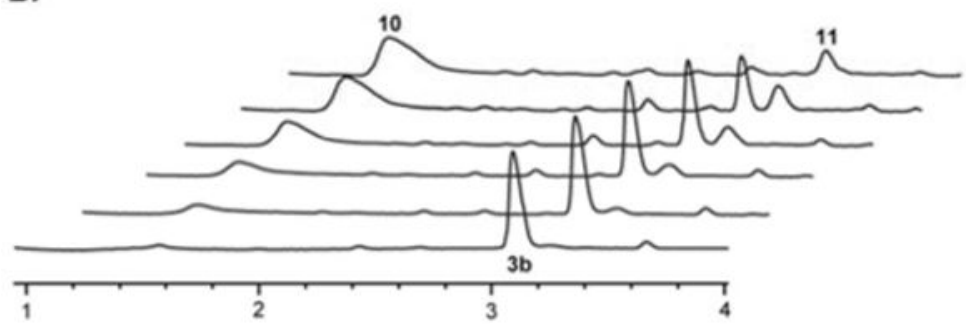

Scheme 4.

A) Uncaging reaction of caged sulfoxide $3 b$ under UV. B) LC traces of the uncaging reaction of $3 b$ in 4 hours. 
A.

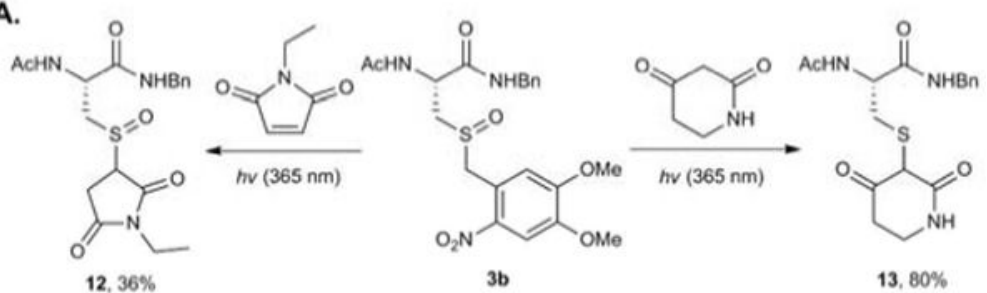

B.

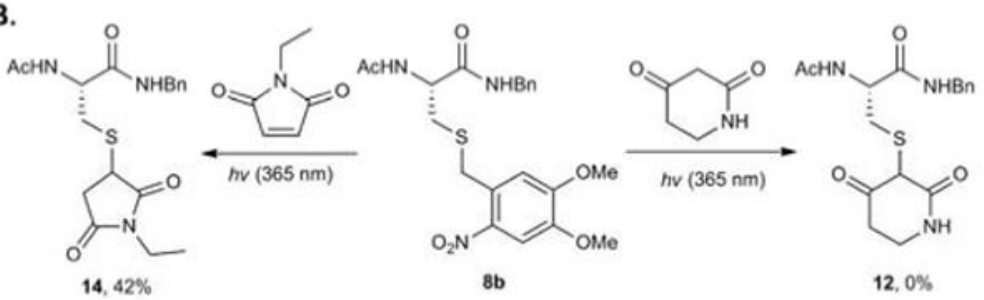

Scheme 5.

Uncaging and chemical trapping of A) caged sulfoxide $3 \mathrm{~b}$, and B) reduced analog $8 \mathrm{~b}$. 
A.

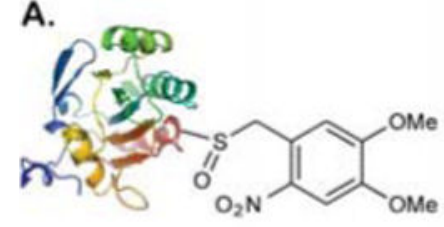

Expected (23061.8 Da)

Observed (23061.0Da)

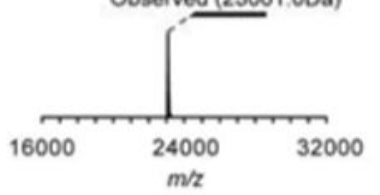

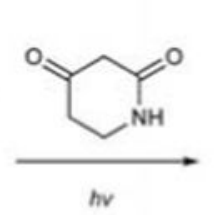

hv

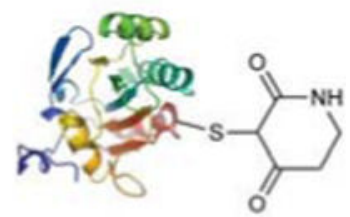

Expected (22962.8 Da)

Observed (22962.0 Da)

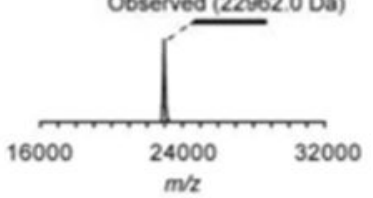

B.

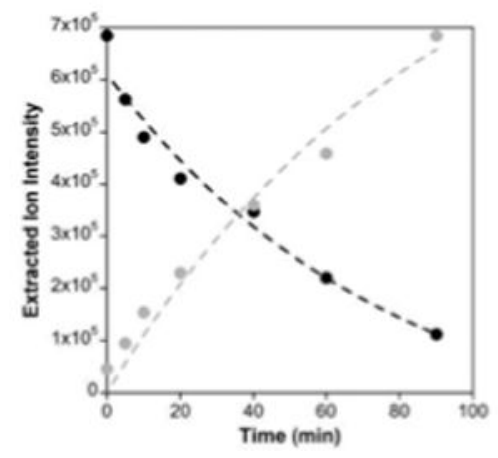

Scheme 6.

Photochemical generation of sulfenic acid in a protein. A) ESI-MS spectrum of intact Gpx3. B) Extracted ion intensities of Gpjg Cys320 consumption (•) and Gpjg-PD formation ( $\bigcirc)$. 